\title{
Socio Economic Status of Sheep Farmers in Western Ghat Region of Virudhunagar District Tamil Nadu, India
}

\author{
G. Srinivasan* and K. Roopa \\ Tamil Nadu Veterinary and Animal Sciences University, Chennai- 600 051, India \\ *Corresponding author
}

\section{A B S T R A C T}

\begin{tabular}{|l||}
\hline Ke y w o r d s \\
Sheep farmers, \\
socio economic \\
status, \\
Virudhunagar, \\
Western Ghat \\
\hline Article Info \\
\hline $\begin{array}{l}\text { Accepted: } \\
\text { 20 June } 2020 \\
\text { Available Online: } \\
\text { 10 July } 2020\end{array}$ \\
\hline
\end{tabular}

A study on socio economic status of sheep farmers was conducted in western ghat region, Virudhunagar district, Tamil Nadu, India. Three blocks namely Watrap, Rajapalayam and Srivilliputhur blocks and three villages from each of the block were selected randomly. In each village, 30 sheep farmers were randomly selected. Data was collected through pre tested questionnaire method. The study revealed that most of the sheep farmers in the western ghat region of Virudhunagar district belonged to age group of 35 to 50 years were illiterate and lived in a nucleus family. Nearly $86.29 \%$ of sheep farmers were landless but $89.63 \%$ owned house, average flock size was more than 50 , and were maintained by grazing for more than 6 hours per day. The farmers depend on government dispensary for veterinary health care. Percentage of only one member of family engaged in sheep farming was $82.59 \%$. Most of the sheep farmers had more than 10 years of experience and were not exposed to any scientific training. Further, they did not wish to attend training to improve their socio economic status. It is suggested that there is a huge opportunity for the farmers of Western Ghat region in Virudhunagar district to apply scientific knowledge and approaches in sheep farming to uplift their socio-economic status.

\section{Introduction}

Sheep and goat are major species of livestock reared by landless labourers and marginal farmers in rural areas and this rearing significantly improves their livelihood. Sheep farming is mainly practiced by the traditional shepherd community who are economically poor farmers following extensive system of rearing. It provides gainful employment and income to the weaker sections especially to the rural poor. Sheep contribute to about 0.77 million metric tons of meat in India which is
$12.1 \%$ of the total meat production in India (Integrated sample survey report, 2007). Virudhunagar district of Tamil Nadu lies between 900 20' and 900 72' of north latitude and 770 20' and 780 70' of east longitude. The district comprises of 10 blocks out of which Watrap, Rajapalayam and Srivilliputhur blocks are situated in the foot hills of Western Ghat. The study area is rich loamy soil with good vegetation cover mostly suitable for animal husbandry activities especially sheep and goat farming. The information related to sheep farming by the 
farmers in this area is very limited. Detailed study is needed to know the present status and recommended scientific sheep farming to improve the livelihood of sheep farmers. Hence, this study was planned to determine the socio-economic status and sheep rearing practices followed in fringe villages of western ghat region in Virudhunagar district

\section{Materials and Methods}

This study was conducted at three blocks of Virudhunagar district located in foothills of Western Ghat. In each block, three villages nearer to the Western Ghat were selected randomly. In each village, 30 sheep farmers were selected randomly to study the socio economic status of the sheep farmers. Data were collected by personal interview through pre tested questionnaire. The base line information about age, education status, family members, community, religion, number of sheep owned, de worming details, training attended, need of training and veterinary care facility available were collected. The data collected were tabulated and statistical parameters like percentage was used for logical conclusion.

\section{Results and Discussion}

\section{Age and education status of head of the family}

Table 1 shows that majority of sheep farmers in western ghat region of Virudhunagar district belong to age group between 35 to 50 years. It was high in Watrap block $(70 \%)$ followed by Rajapalayam and Srivilliputhur block. Overall $56.67 \%$ of farmers were belonging to 35-50 years age group followed by $28.15 \%$ and $15.19 \%$ of farmers more than 50 years age group and 25 to 35 years age group respectively. Results of these findings agreed with Rajanna et al., (2012) who reported that mean age group of sheep farmers of Telangana zone of Andhra Pradesh was 42.69 years. Similar reports were reported by Balusamy (2004) and Mishra et al (2004). It shows that most of the young age people prefer other profession than traditional sheep farming. But sheep farming is still followed by middle age group and old age people in the study area. But Geeta et al., (1999) reported that $31.61 \%$ of sheep farmers in Karnataka state were young age followed by $25.51 \%$ middle age group.

\section{Family members}

Most of the sheep farmers $(86.3 \%)$ in western ghat region of Virudhunagar district belonged to nucleus family (Table 1). Percentage of Nucleus family was high in Watrap block (94.44) followed by Srivilliputhur (84.44) and Rajapalayam block (80). It indicates that the joint family system is slowly declining even in villages. Results of this finding agreed with Sathyanarayanan et al., (2010) who reported that majority $(63.08 \%)$ of livestock farmers lived in nucleus family and $36.92 \%$ belonged to joint family. Thilakar and Krishnaraj (2010) reported that $50 \%$ farmers had 4-5 members in their family. But findings are disagreed with Rajanna et al., (2012) reported that $73.96 \%$ of sheep farmers in Telangana region of Andhra Pradesh belonged to joint family. It was general perception that sheep farmers prefer bigger family to share their work load but this trend is slowly decreasing.

\section{Educational status of head of family}

Based on the education status of the head of family they were grouped in to illiterate, primary school, middle school, high school, higher secondary and graduate (Table.1). Educational status of head of the family is important criteria for the socio economic status of the family. Overall, $67.40 \%$ of sheep farmers in western ghat region of Virudhunagar district were illiterate followed 
by $15.19 \%, 10.37 \%, 1.85 \%, 1.85 \%$ of sheep farmers completed primary school education, middle school education, high school and higher secondary school education respectively. Interestingly, $10 \%$ of sheep farmers completed graduation only in Rajapalayam block which has comparatively more colleges than other blocks in that region. Results of this finding agreed with Patil et al., (2012) who revealed that that majority of the sheep farmers $(60 \%)$ in Dhangar Pastoralists of Maharashtra, were illiterate, followed by Primary (23), secondary school (15\%) and high school $(1 \%)$. However, results of this finding disagreed with Hossain et al., (2018) who reported that $60 \%$ of sheep farmers in Gafargaon upazila of Mymensingh district in Bangaledesh completed primary education and $27 \%$ of sheep farmers were illiterate. Villages of Western Ghat region had poor accessibility to school education may be one of the reason for more illiterates in the study area.

\section{Community, religion and marital status}

Majority $(71.85 \%)$ of the sheep farmers in the western ghat region of Virudhunagar district belonged to Other Backward community (OBC) and $28.15 \%$ belonged to scheduled caste community (Table 1). Sheep farmers belonging to Scheduled caste community was higher in Watrap block (44.45\%) followed by $40 \%$ in Rajapalayam block. Results are agreed with Rajanna et al., (2012) who reported that majority of sheep farmers in Telangana region of Andhra Pradesh belonged to backward community $(97.40 \%)$ followed by $1.22 \% \quad 0.87 \%$ and $0.52 \%$ Scheduled tribe, forward caste and scheduled caste respectively.

In Watrap and Srivilliputhur blocks most of the sheep farmers belonged to Hindu religion (Table 1). Only in Rajapalayam block $5.56 \%$ sheep farmers belonged to Christian religion.
In overall study area, $98.15 \%$ and $1.85 \%$ sheep farmers were belonged to hindu and Christian religion respectively. Similar results were observed by Thiruvenkadan et al., (2004) who reported that $99.32 \%$ sheep farmers in the survey area were hindus followed by Christians and Muslims. This finding was also supported by Kandasamy et al., (2006). But Porwal et al., (2006) reported that Muslim were second in row after Hindus in Western Rajasthan. This variation in religion could be due to geographical distribution of population.

Percentage of Married persons involved in sheep farming were 100,100 and 90 in Watrap, Rajapalayam and Srivilliputhur block respectively. Overall $96.67 \%$ sheep farmers were married and $3.33 \%$ were unmarried. It is revealed that sheep farming is followed as family enterprises in western ghat region of Virudhunagar district This findings was supported by Fakoya and Oloruntoba, (2009) reported that majority $(72.5 \%)$ of sheep farmers in Osun state, Nigeria are married.

\section{Income from other sources}

Only in Rajapalayam block $10 \%$ sheep farmers were involved in other work to earn additional income along with sheep farming. Overall study area, only 3.33\% sheep farmers involved in other work to earn additional income (Table 1). It indicates that the income from sheep farming was sufficient for majority of them $(96.67 \%)$.

\section{House status:}

Table 2 shows house status data. In Watrap blocks majority of $(100 \%)$ of sheep farmers had own house followed by $94.44 \%$ and $74.44 \%$ in Srivilliputhur block and Rajapalayam block respectively. Overall $89.63 \%$ of sheep farmers had own house and $10.37 \%$ of Sheep farmers were living in 
rented house. It showed that average income of the sheep farmers did not influence the housing status. This finding was in disagreement with that reported by Rajanna et al., (2012) who observed that $80.73 \%$ of shepherds in Telangana region possessed kutcha house and only $19.27 \%$ had RCC stone structured own house.

\section{Land holding}

Table 2 shows data on land holding pattern. Most of the sheep farmers in western ghat region of Virudhunagar district were landless ( $86.29 \%$ ) followed by $8.52 \%$ and $5.19 \%$ of sheep farmers who possessed large and small land respectively. Only in Srivilliputhur block $20 \%$ of sheep farmer possessed large land. Similar finding was reported by Hossain et al., (2018) who stated that the major category (50\%) of the farmers belonged to marginal class, 33\% farmer's owned small, and 17\% medium size of land in Gafargaon upazila of Mymensingh district. This finding was also supported by Ramesh et al., (2012) and Sastry et al., (1992).

Table.1 Personal and Social status of the sheep farmers (\%)

\begin{tabular}{|c|c|c|c|c|c|}
\hline $\begin{array}{l}\text { S. } \\
\text { No. }\end{array}$ & Personal and Social status & Rajapalayam & Watrap & Srivilliputhur & $\begin{array}{c}\text { Overall } \\
\text { (F) }\end{array}$ \\
\hline $\mathbf{A}$ & \multicolumn{5}{|c|}{ Age } \\
\hline & $18-25$ & 0 & 0 & 0 & 0.00 \\
\hline & $25-35$ & 15.56 & 10 & 20 & 15.19 \\
\hline & $35-50$ & 50 & 70 & 50 & 56.67 \\
\hline & More than 50 & 34.44 & 20 & 30 & 28.15 \\
\hline B & \multicolumn{5}{|c|}{ Family members } \\
\hline & Nucleus family & 80 & 94.44 & 84.44 & 86.30 \\
\hline & Joint family & 20 & 5.56 & 15.56 & 13.70 \\
\hline $\mathbf{C}$ & \multicolumn{5}{|c|}{ Education status of head of family } \\
\hline & Illiterate & 68.88 & 64.44 & 68.88 & 67.40 \\
\hline & Primary school & 15.56 & 10 & 20 & 15.19 \\
\hline & Middle school & 0 & 25.56 & 5.56 & 10.37 \\
\hline & High school & 0 & 0 & 5.56 & 1.85 \\
\hline & Higher secondary & 5.56 & 0 & 0 & 1.85 \\
\hline & Graduate & 10 & 0 & 0 & 3.33 \\
\hline D & \multicolumn{5}{|c|}{ Community } \\
\hline & $\mathrm{OC}$ & 0 & 0 & 0 & 0.00 \\
\hline & $\mathrm{OBC}$ & 60 & 55.55 & 100 & 71.85 \\
\hline & $\mathrm{SC}$ & 40 & 44.45 & 0 & 28.15 \\
\hline $\mathbf{E}$ & \multicolumn{5}{|c|}{ Religion } \\
\hline & Hindu & 94.44 & 100 & 100 & 98.15 \\
\hline & Christian & 5.56 & 0 & 0 & 1.85 \\
\hline $\mathbf{F}$ & \multicolumn{5}{|c|}{ Marital Status } \\
\hline & Married & 100 & 100 & 90 & 96.67 \\
\hline & Un married & 0 & 0 & 10 & 3.33 \\
\hline $\mathbf{G}$ & \multicolumn{5}{|c|}{ Engaged in other business } \\
\hline & Yes & 10 & 0 & 0 & 3.33 \\
\hline & No & 90 & 100 & 100 & 96.67 \\
\hline
\end{tabular}


Table.2 Land holding and house status (\%)

\begin{tabular}{|l|l|l|l|l|l|}
\hline $\begin{array}{l}\text { S. } \\
\text { No }\end{array}$ & Land and house status & Rajapalayam & Watrap & Srivilliputhur & $\begin{array}{l}\text { Overall } \\
\text { (F) }\end{array}$ \\
\hline A & House status & & & & \\
\hline & Own house & 74.44 & 100 & 94.44 & 89.63 \\
\hline & Rented house & 25.56 & 0 & 5.56 & 10.37 \\
\hline B & Land holding & & & & \\
\hline & No land & 94.44 & 94.44 & 70 & 86.29 \\
\hline & Small & 5.56 & 0 & 10 & 5.19 \\
\hline & Medium & 0 & 0 & 0 & 0.00 \\
\hline & Large & 0 & 5.56 & 20 & 8.52 \\
\hline
\end{tabular}

Table.3 Flock size, Veterinary health care and deworming per year (\%)

\begin{tabular}{|l|l|l|l|l|l|}
\hline $\begin{array}{l}\text { S. } \\
\text { No }\end{array}$ & Characters & Rajapalayam & Watrap & Srivilliputhur & Overall (F) \\
\hline A & Flock size & \multicolumn{5}{|l|}{} \\
\hline & Less than 10 & 34.44 & 15.56 & 0.00 & 16.67 \\
\hline & $10-30$ & 0.00 & 25.56 & 15.56 & 13.70 \\
\hline & $30-50$ & 0.00 & 15.56 & 5.56 & 7.04 \\
\hline & More than 50 & 65.56 & 43.33 & 78.89 & 62.59 \\
\hline B & Veterinary health care dependency & & & \\
\hline & Own treatment & 65.56 & 20.00 & 21.11 & 35.56 \\
\hline & Government dispensary & 34.44 & 80.00 & 78.89 & 64.44 \\
\hline & Private practitioner & 0 & 0 & 0 & 0.00 \\
\hline C & Number of De-worming/year & & & \\
\hline & One time & 5.56 & 0.00 & 10.00 & 5.19 \\
\hline & Two times & 34.44 & 54.44 & 30.00 & 39.63 \\
\hline & Three times & 60.00 & 45.56 & 60.00 & 55.19 \\
\hline
\end{tabular}

Table.4 Grazing time and family members engaged (\%)

\begin{tabular}{|l|l|l|l|l|l|}
\hline $\begin{array}{l}\text { S. } \\
\text { No }\end{array}$ & Characters & Rajapalayam & Watrap & Srivilliputhur & $\begin{array}{l}\text { Overall } \\
(\mathbf{F})\end{array}$ \\
\hline A & Grazing & & & \\
\hline & Less than 6 hours/day & 10.00 & 5.56 & 0.00 & 5.19 \\
\hline & More than 6 hours/day & 90.00 & 94.44 & 100.00 & 94.81 \\
\hline B & Family Members engaged in sheep farming \\
\hline & Single & 74.44 & 94.44 & 78.89 & 82.59 \\
\hline & 2-3 members & 25.56 & 5.56 & 21.11 & 17.41 \\
\hline & More than 3 members & 0.00 & 0.00 & 0.00 & 0.00 \\
\hline
\end{tabular}


Table.5 Experience, exposure to training Centre (\%)

\begin{tabular}{|c|c|c|c|c|c|}
\hline $\begin{array}{l}\text { S. } \\
\text { No }\end{array}$ & Characters & Rajapalayam & Watrap & Srivilliputhur & $\begin{array}{l}\text { Overall } \\
\text { (F) }\end{array}$ \\
\hline \multirow[t]{3}{*}{ A } & \multicolumn{5}{|l|}{ Experience } \\
\hline & Less than 10 years & 45.55 & 40.00 & 30.00 & 38.52 \\
\hline & More than 10 years & 54.45 & 60.00 & 70.00 & 61.48 \\
\hline \multirow[t]{5}{*}{ B } & \multicolumn{5}{|c|}{ Exposure to training institute } \\
\hline & Exposed & 0.00 & 0.00 & 0.00 & 0.00 \\
\hline & Not exposed & 100.00 & 100.00 & 100.00 & 100.00 \\
\hline & $\begin{array}{l}\text { Need training on sheep } \\
\text { farming }\end{array}$ & 64.44 & 15.56 & 35.56 & 38.52 \\
\hline & $\begin{array}{l}\text { No need training on sheep } \\
\text { farming }\end{array}$ & 35.56 & 84.44 & 64.44 & 61.48 \\
\hline
\end{tabular}

\section{Flock size}

It could be observed from Table 3 that majority $(62.59 \%)$ of sheep farmers in all three blocks owned more than 50 sheep followed by less than 10 sheep $(16.67 \%), 10$ 30 sheep (13.70\%) and 30-50 sheep (7.04\%). Percentages of sheep farmers owned more than 50 sheep were high in Srivilliputhur block (78.89). Similar finding also reported by Patil et al., (2012) in Maharastra that average sheep per family in Sangli district was 55.55 and 83.41 in Kolhapur district. Overall average sheep per family was found 69.48. Whereas Geeta et al., (1999) observed that majority of sheep farmers had a flock size of 30 sheep and $20 \%$ farmers had up to 50 sheep with a mean of 28 sheep per flock. Chandran et al., (2009) reported that mean flock size of Vembur sheep was 38.6.

\section{Veterinary health care dependency and number of deworming}

Data on veterinary health care dependency is given in table 3. Overall $64.44 \%$ of sheep farmers in the study area depended on government veterinary dispensary their animal health care. However, $35.56 \%$ of sheep farmers gave their own treatment for their sheep. Percentage of farmers giving own treatment was high in Rajapalayam block (65.56). In overall study area $55.19 \%$ of sheep farmers carried out three times deworming and $39.63 \%$ of farmers carried out two times deworming per year for their sheep (Table 3). In general awareness about importance of deworming was high in this study area.

\section{Grazing time}

Grazing time per day is shown in Table 4. Majority of the sheep farmers (94.81\%) in the study area allowed their sheep for more than 6 hrs per day only $5.19 \%$ of sheep farmers allowed for less than 6 hours grazing per day. Less than 6 hours grazing was high (10\%) in Rajapalayam block this could be due to that flock size less than 10 sheep per family was high in that block.

\section{Members engaged in sheep farming}

The percentage of family members engaged in sheep farming is shown in Table 4. In the study area only one member of the family involved in sheep farming was $82.59 \%$ followed by two to three members of family engaged was $17.41 \%$. Two to three members of the family engaged in sheep farming was high in Rajapalayam block (25.56\%) followed by Srivilliputhur block (21.11\%). In overall 
study area, single person mostly head of the family involved in sheep farming. Patil et al (2012) who reported that involvement of women in the sheep husbandry practices was found less as compared to male in Maharastra. Whereas Raghavan and Raja, (2012) reported that goat rearing in Malabar region of Kerala is mainly in the hands of women.

\section{Experience and exposure to training centre}

Experience in sheep farming among the farmers in study area is shown in Table 6.

Experience of farmers in sheep farming more than 10 years and less than 10 years were $61.48 \%$ and $38.52 \%$ respectively. This finding was in agreement with Hassan et al (2015) who observed that 57\% sheep farmers in Lafia, Nigeria had more than 10 years of experience and $43 \%$ had less than 10 years experience in sheep farming. Most of the sheep farmers $(100 \%)$ in study area were not exposed or accessed training centre, Compared to other blocks illiterate sheep farmers percentage was high in Rajapalayam block even though $64.44 \%$ of sheep farmers wish to attend training on sheep farming. $84.44 \%$ sheep farmers in Watrap block and $64.44 \%$ in Srivilliputhur block did not wish to attend training. This could be due to more distance to training centre and no awareness about the importance of scientific farming to improve their socio economic status.

In conclusion the study reveals that most of the sheep farmers in the western ghat region of Virudhunagar district belonged to 35 to 50 years of age are illiterate and live in nucleus family. Nearly $86.29 \%$ of sheep farmers are landless, but $89.63 \%$ owned house and had an average flock size of more than 50, maintained their sheep by grazing for more than 6 hours per day. They depend on government dispensary for veterinary health care. In $82.59 \%$ of famers only one member of family engaged in sheep rearing. Most of the sheep farmers had more than 10 years experience were not trained or did not wish to attend training to improve their socio economic status. It is suggested that there is a huge opportunity for the farmers of western ghat region in Virudhunagar district to apply scientific knowledge and approaches in sheep farming to uplift their socio-economic status.

\section{References}

Balusamy, C., 2004. Productive and reproductive performance of buffaloes in North-Eastern zone of Tamil Nadu (Doctoral dissertation, Ph. D Thesis submitted to Tamil Nadu Veterinary and Animal Sciences University, Chennai-600051).

Chandran, P.C., Kandasamy, N. and Panneerselvam, S., 2009. Distribution, characteristics and management of Vembur sheep. Indian Journal of Animal Sciences, 79(1):73-77.

Fakoya, E.O. and Oloruntoba, A., 2009. Socio-economic determinants of small ruminants production among farmers in Osun state, Nigeria. Journal of Humanities, Social Sciences and Creative Arts, 4(1):90-100.

Geeta, M., Sunanda, K. and Bhavani, K., 1999. Karnataka-Sheep farmers. The Indian Journal of Small Ruminants, 5(2):82-84.

Hassan, D.I., Mbap, S.T. and Naibi, S.A., 2015. Socio-economic characteristics of yankasa sheep and west african dwarf goat's farmers and their production constraint in lafiya Nigeria. Int. J. Food Agric. Vet. Sci, 5: 82-93.

Hossain, M.A., Islam, M.A., Akhtar, A., Islam, M.S. and Rahman, M.F., 2018. Socioeconomic status of sheep farmers and the management practices of sheep 
at Gafargaon upazila of Mymensingh district. International Journal of Natural and Social Sciences, 5(4):0715.

Integrated Sample Survey report on estimation of production of Milk, Egg, Meat \& Wool for the (2007-2008) of Animal Husbandry Department, Andhra Pradesh

Kandasamy, N., Paneerselvam, S., Devendran, P. and Thiruvenkadan, A.K., 2006. Final report on survey evaluation and characterization of Coimbatore sheep breed. Department of Animal Genetics and Breeding, $V C \& R I$, Namakkal.

Mishra, P.K., Barik, N., Patro, B.N. and Nayak, S., 2004. Production potentiality of Ganjam sheep under extensive management. The Indian Journal of Small Ruminants, 10(2):171-172.

Patil, D.S., Meena, H.R., Tripathi, H., Kumar, S. and Singh, D.P., 2012. Socioeconomic profile of sheep reared Dhangar pastoralists of Maharashtra, India. J Rec Adv Agri, 1(3):84-91.

Porwal, K., Karim, S.A., Sisodia, S.L. and Singh, V.K., 2006. Socio-economic survey of sheep farmers in western Rajasthan. The Indian Journal of Small Ruminants, 12(1):74-81.

Raghavan, K.C. and Raja, T.V., 2012. Analysis on the socio-economic status of the goat farmers of Malabar Region of Kerala. Veterinary research, 5(4): 74-76.
Rajanna, N., Mahender, M., Thammiraju, D., Raghunadan, T., Nagalakshmi, D. and Sreenivasa Rao, D., 2012. Socioeconomic status and flock management practices of sheep farmers in Telangana region of Andhra Pradesh. Veterinary Research, 5(2):3740.

Ramesh, H.R., Socio-Economic Status of Small Ruminant Farmers in Different Agro-Climatic Zones of Karnataka, India. 2012

Sastry, N.S.R., Butterdieck, P. and Ch. F. Gall. 1992. Economics performance of different ruminants livestock keeping systems of rural households in the southern Indian province.Indian $J$. Anim. Sci., 62 (1):1083-1091

Sathyanarayan, K., Jagadeeswary, V., Murthy, V.C., Ruban, S.W. and Sudha, G., 2010. Socio-economic status of livestock farmers of Narasapura Village-A Benchmark analysis. Veterinary World, 3(5):215.

Thilakar, P. and Krishnaraj, R., 2010. Profile characteristics of sheep farmers: A survey in Kancheepuram district of Tamil Nadu. Indian Journal of Field Veterinarians (The), 5(3): 35-36.

Thiruvenkadan, A.K., Karunanithi, K. and Purushothaman, M.R., 2004. Socioeconomic status of the mecheri sheep farmers and economics of rearing under farmer's management. The Indian Journal of Small Ruminants, 10(2):117-122.

\section{How to cite this article:}

Srinivasan, G. and Roopa, K. 2020. Socio Economic Status of Sheep Farmers in Western Ghat Region of Virudhunagar District Tamil Nadu, India. Int.J.Curr.Microbiol.App.Sci. 9(07): 24372444. doi: https://doi.org/10.20546/ijcmas.2020.907.286 